\title{
Can Adverse Effects of Acidity and Aluminum Toxicity Be Alleviated by Appropriate Rootstock Selection in Cucumber?
}

\section{OPEN ACCESS}

Edited by:

Elena Prats,

Spanish National Research Council,

Spain

Reviewed by:

Paolo Sambo,

University of Padua, Italy

Spyridon Alexandros Petropoulos,

University of Thessaly, Greece

*Correspondence:

Giuseppe Colla

giucolla@unitus.it

${ }^{\dagger}$ In Memoriam:

This article is dedicated to our deceased friend and colleague

Dr. Elvira Rea, scientist in plant physiology and plant nutrition. She was a close and helpful collaborator over many years and made a significant contribution to this research.

Specialty section: This article was submitted to Crop Science and Horticulture, a section of the journal Frontiers in Plant Science

Received: 29 May 2016 Accepted: 11 August 2016 Published: 29 August 2016

Citation:

Rouphael Y, Rea E, Cardarelli M, Bitterlich M, Schwarz D and Colla G (2016) Can Adverse Effects of Acidity and Aluminum Toxicity Be Alleviated by Appropriate Rootstock Selection in Cucumber? Front. Plant Sci. 7:1283. do: 10.3389/fpls.2016.01283

\section{Youssef Rouphael ${ }^{1}$, Elvira Rea ${ }^{2 \dagger}$, Mariateresa Cardarelli ${ }^{2}$, Michael Bitterlich ${ }^{3}$, Dietmar Schwarz ${ }^{3}$ and Giuseppe Colla ${ }^{4 *}$}

\begin{abstract}
'Department of Agricultural Sciences, University of Naples Federico II, Naples, Italy, ${ }^{2}$ Centro di Ricerca per lo Studio delle Relazioni tra Pianta e Suolo, Consiglio per la Ricerca in Agricoltura e l'Analisi dell'Economia Agraria, Rome, Italy, ${ }^{3}$ Leibniz Institute of Vegetable and Ornamental Crops, Großbeeren, Germany, ${ }^{4}$ Department of Agricultural and Forestry Sciences, University of Tuscia, Viterbo, Italy
\end{abstract}

Low-pH and aluminum (Al) stresses are the major constraints that limit crop yield in acidic soils. Grafting vegetable elite cultivars onto appropriate rootstocks may represent an effective tool to improve crop tolerance to acidity and Al toxicity. Two greenhouse hydroponic experiments were performed to evaluate growth, yield, biomass production, chlorophyll index, electrolyte leakage, mineral composition, and assimilate partitioning in plant tissues of cucumber plants (Cucumis sativus L. "Ekron") either non-grafted or grafted onto "P360" (Cucurbita maxima Duchesne × Cucurbita moschata Duchesne; E/C) or figleaf gourd (Cucurbita ficifolia Bouché; E/F). Cucumber plants were cultured in pots and supplied with nutrient solutions having different $\mathrm{pH}$ and $\mathrm{Al}$ concentrations: $\mathrm{pH}$ 6, pH 3.5, pH $3.5+1.5 \mathrm{mM} \mathrm{Al}$, and pH $3.5+3 \mathrm{mM} \mathrm{Al}$ (Experiment 1, 14 days) and $\mathrm{pH}$ 6, pH 3.5, and pH $3.5+0.75 \mathrm{mM} \mathrm{Al}$ (Experiment 2, 67 days). Significant depression in shoot and root biomass was observed in response to acidity and Al concentrations, with Al-stress being more phytotoxic than low pH treatment. Significant decrease in yield, shoot, and root biomass, leaf area, SPAD index, $\mathrm{N}, \mathrm{K}, \mathrm{Ca}, \mathrm{Mg}, \mathrm{Mn}$, and $\mathrm{B}$ concentration in aerial parts (leaves and stems) in response to low $\mathrm{pH}$ with more detrimental effects at $\mathrm{pH} 3.5$ + Al. Grafted E/C plants grown under low pH and Al had higher yield, shoot, and root biomass compared to $\mathrm{E} / \mathrm{F}$ and non-grafted plants. This better crop performance of $\mathrm{E} / \mathrm{C}$ plants in response to Al stress was related to (i) a reduced translocation of Al from roots to the shoot, (ii) a better shoot and root nutritional status in $\mathrm{K}, \mathrm{Ca}, \mathrm{Mg}, \mathrm{Mn}$, and $\mathrm{Zn}$ concentration, (iii) a higher chlorophyll synthesis, as well as (iv) the ability to maintain cell membrane stability and integrity (lower electrolyte leakage). Data provide insight into the role of grafting on Al stress tolerance in cucumber.

Keywords: Al tolerance, chlorophyll index, Cucumis sativus L., graft combination, membrane stability, mineral composition, $\mathrm{pH}$ level 


\section{INTRODUCTION}

Acidic soils represent 50\% of the earth's arable land (InostrozaBlancheteau et al., 2012), and in those soils aluminum (Al) toxicity is the main factor restricting crop productivity (Kochian, 1995). In acidic soils with $\mathrm{pH}$ lower than 5, Al-containing minerals (e.g., aluminosilicates) are solubilized in the phytotoxic form $\mathrm{Al}^{3+}$ (Kochian, 1995; Seguel et al., 2013). The root is the first organ feeling $\mathrm{Al}^{3+}$ toxicity, thus conditioning stress sensitivity and hampering crop productivity (Delhaize and Ryan, 1995; Rengel et al., 2015). For many plant species, Al concentration in the range of $1-2 \mathrm{mg} \mathrm{L}^{-1}$ can inhibit root elongation by damaging the cell structure of the root apex and thus influencing water and nutrient uptake (Kochian et al., 2015; Rengel et al., 2015). Al also interferes with cell membrane stability, enzyme function, and the synthesis of chlorophyll (Simon et al., 1994; Rouphael et al., 2015). Several authors reported that exposure to $\mathrm{Al}^{3+}$ in the rooting medium strongly inhibit $\mathrm{Ca}^{2+}$ and $\mathrm{Mg}^{2+}$ fluxes across the plasma membrane of root cells (Rengel and Elliott, 1992; Horst et al., 2010; Bose et al., 2011). Similarly, Al toxicity can decease or even block the uptake of $\mathrm{K}^{+}$, since it interacts with various different plasma-membrane channel proteins (Kochian et al., 2005). This may decrease cations uptake leading to nutrient deficiencies, thus affecting metabolism and productivity of crops. However, plant species have different degrees of adaptation to $\mathrm{Al}$; these differences are often related to the specific mechanisms developed for mitigating stress (Panda and Matsumoto, 2007). The mechanisms conferring tolerance to Al have been classified into mechanisms of exclusion and those of intracellular tolerance (Kochian, 1995). Exclusion mechanisms not allowing $\mathrm{Al}$ entering the symplast can take place by exudation of Al-chelating compounds (e.g., organic acids), raising the $\mathrm{pH}$ in the rhizospheric environment and by binding of $\mathrm{Al}$ in the cell wall itself (Inostroza-Blancheteau et al., 2012; Brunner and Sperisen, 2013; Kochian et al., 2015). Internal tolerance mechanisms include those that bind the $\mathrm{Al}$ entering the root cells as well as the sequestration of $\mathrm{Al}$ in subcellular compartments (e.g., vacuoles).

To overcome the limitations of Al toxicity several solutions have been proposed. Amendments such as gypsum, lime, and phosphate fertilizers are common agricultural practices used to raise the soil $\mathrm{pH}$ causing the $\mathrm{Al}$ to become insoluble (Nawrot et al., 2001). Liming is only efficient in the topsoil, while it does not remedy the subsoil acidity $(>1 \mathrm{~m})$, since deep incorporation of lime is difficult to realize and very costly (Choudhary and Singh, 2011; Yang et al., 2013). Another possible solution to alleviate the negative effects of acid soils would be the use Altolerant cultivars obtained by breeding and/or biotechnological approaches (Choudhary and Singh, 2011). However, the long time needed for the breeding of Al-tolerant cultivars as well as the complexity of the Al-trait make this task extremely difficult. In order to overcome this situation more rapidly, grafting elite vegetable cultivars onto rootstocks tolerating higher $\mathrm{Al}$ concentrations and low $\mathrm{pH}$ could be a key tool in alleviating the effects of acidity and Al toxicity on crop productivity.

By selecting suitable rootstocks, grafting can control scion morphology (Albacete et al., 2015), increase productivity and fruit quality (Colla et al., 2008; Proietti et al., 2008; Kyriacou et al., 2016), improve nitrogen use efficiency (Colla et al., 2010a, 2011), and also induce tolerance against several abiotic stresses, among them nutrient toxicity, heavy metals, and alkalinity (Edelstein et al., 2005, 2007; Rouphael et al., 2008a,b; Colla et al., 2010b; Savvas et al., 2010, 2013; Kumar et al., 2015a). Therefore, we hypothesized that the effectiveness of root genotypes to enhance the uptake of nutrients and to limit the $\mathrm{Al}$ accumulation in aerial parts may be improved by grafting onto suitable rootstocks.

To verify the above hypothesis, two hydroponic greenhouse experiments were conducted (1) to assess the effects of grafting combinations on morphological traits of cucumber at early development stage in response to different nutrient solution $\mathrm{pH}$ and $\mathrm{Al}$ concentrations; and (2) to elucidate the agronomical, physiological, and mineral composition changes of cucumber mediated by grafting under acidity and $\mathrm{Al}$ toxicity conditions using long-term treatments.

\section{MATERIALS AND METHODS \\ Plant Material Selection and Growth Conditions}

A short- and a long-term experiment were performed to characterize the response to acidity and Al toxicity in cucumber (Cucumis sativus L.) either non-grafted or grafted onto vigorous rootstocks. Both experiments were conducted in a polyethylene greenhouse at the experimental station of the University of Tuscia, located in Viterbo (latitude $42^{\circ} 25^{\prime} \mathrm{N}$, longitude $12^{\circ} 08^{\prime} \mathrm{E}$, altitude $310 \mathrm{~m}$ ). Inside the greenhouse the mean air temperatures amounted to $25^{\circ} \mathrm{C}$ varying between 18 and $30^{\circ} \mathrm{C}$, while the mean day/night relative humiditiy was $55 / 80 \%$.

In the short-term experiment (Experiment 1), C. sativus L. "Ekron" (E; Enza Zaden, Verona, Italy) was grafted onto the commercial rootstock "P360" (C; Cucurbita maxima $\times$ Cucurbita moschata; Società Agricola Italiana Sementi, Cesena, Italy), whereas in the long-term experiment (Experiment 2) cucumber "Ekron" was grafted onto the "P360" and also onto the figleaf gourd (F) (Cucurbita ficifolia Bouché; Società Agricola Italiana Sementi, Cesena, Italy) using the procedure of insertion grafting (Lee et al., 2010). In both experiments the non-grafted "Ekron" was used as control. The Cucurbita hybrid "P360" and the figleaf gourd were selected as the most representative commercial rootstocks used in the Mediterranean basin and Asia, respectively (Lee et al., 2010). In Experiment 1, grafted and nongrafted seedlings were transplanted 20 days after sowing, at the two true-leaf stages into plastic pots of $2 \mathrm{~L}$ volume (one plant per pot) filled with quartziferous sand and placed over $16 \mathrm{~cm}$ wide and $5 \mathrm{~m}$ long benches at a plant density of 11 plants $\mathrm{m}^{-2}$. In Experiment 2, cucumber seedlings were transplanted on 22 May into pots containing $17.7 \mathrm{~L}$ of quartziferous sand. Pots were disposed in double rows at a plant density of 2.5 plants $\mathrm{m}^{-2}$, as used commercially for cucumber under greenhouse conditions. Cucumber plants were grown as vertical cordons and trained to the umbrella system as described by Rouphael et al. (2010). 


\section{Experimental Design, Treatments, and Nutrient Solution Management}

Experiment 1 contained eight treatments, derived by the factorial combination of two grafting combinations (grafted E/C and nongrafted E plants) and four nutrient solutions ( $\mathrm{pH} 6.0, \mathrm{pH} 3.5, \mathrm{pH}$ $3.5+1.5 \mathrm{mM} \mathrm{Al}$, and $\mathrm{pH} 3.5+3.0 \mathrm{mM} \mathrm{Al}$ ). Any treatment had four replications, amounting to a total of 32 experimental unit plots with eight plants each ( $n=256$ plants). In Experiment 2, nine treatments, derived by the factorial combination of three grafting combinations (non-grafted $\mathrm{E}$, grafted $\mathrm{E} / \mathrm{C}$ and $\mathrm{E} / \mathrm{F}$ ) and three nutrient solutions ( $\mathrm{pH} 6.0, \mathrm{pH} 3.5$, and $\mathrm{pH} 3.5+0.75 \mathrm{mM}$ $\mathrm{Al}$ ) were compared with four replications, amounting to a total of 36 experimental unit plots ( $n=180$ plants). Each experimental unit consisted of five plants.

Plants were drip-irrigated automatically 2-4 times per day in Experiment 1 and 3-10 times in Experiment 2, to ensure adequate substrate moisture (Colla et al., 2012, 2013). The basic nutrient solution ( $\mathrm{pH}$ 6.0) was a modified Hoagland and Arnon formulation containing the following macro- and micronutrients: $13.0 \mathrm{mM} \mathrm{N}-\mathrm{NO}_{3}^{-}, 1.6 \mathrm{mM} \mathrm{S}, 0.3 \mathrm{mM} \mathrm{P}, 4.3 \mathrm{mM} \mathrm{K}$, $4.0 \mathrm{mM} \mathrm{Ca}, 1.3 \mathrm{mM} \mathrm{Mg}, 20 \mu \mathrm{M} \mathrm{Fe}, 9 \mu \mathrm{M} \mathrm{Mn}, 0.3 \mu \mathrm{M} \mathrm{Cu}, 1.6 \mu \mathrm{M}$ $\mathrm{Zn}, 20 \mu \mathrm{M}$ B, and $0.3 \mu \mathrm{M}$ Mo. The low pH (3.5) treatments had the same basic nutrient composition plus $\mathrm{HCl}$ which was added to decrease the nutrient solution $\mathrm{pH}$, thus simulating the effects of acidity. The $\mathrm{Al}$ treatments were generated by adding $\mathrm{AlCl}_{3} \cdot 6$ $\mathrm{H}_{2} \mathrm{O}$ to the basic nutrient solution. The stressed treatments $(\mathrm{pH}$ 3.5 and $\mathrm{pH} 3.5+\mathrm{Al}$ ) started at transplanting in Experiment 1, and 7 days after transplanting in Experiment 2.

\section{Yield Assessment and Growth Measurements}

In Experiment 2, fruits of all plants were harvested manually 2-3 times per week from 16 June to 25 July. The number of fruits per plant, the mean fruit weight, and the marketable yield were recorded. At final harvest, all plants were separated into leaves, stems and roots, and dried in a forced-air oven at $80^{\circ} \mathrm{C}$ for $72 \mathrm{~h}$ for biomass determination. Root-to-shoot ratio was calculated by dividing root dry weight by the sum of leaf and stem dry weights. The final leaf area was also measured with an electronic leaf area meter (Delta-T Devices Ltd., Cambridge, UK).

\section{Fruit Quality Analysis}

On 1 July (43 days after transplanting), five fruits were sampled from each plot for quality analysis. Fruit shape index (SI) was defined by the ratio of equatorial and longitudinal lengths. Fruit firmness was measured using a penetrometer (Bertuzzi FT 011; Brugherio, Milan, Italy), fitted with an $8 \mathrm{~mm}$-diameter roundhead probe. A part of the homogenate prepared under low speed and filtered under cheesecloth was used for determining the total soluble solid content at $20^{\circ} \mathrm{C}$ using an Atago N1 refractometer (Atago Co. Ltd., Japan). The $\mathrm{pH}$ of the juice was measured with a $\mathrm{pH}$ electrode (HI-9023, Hanna Instruments, Padova, Italy). The titratable acidity of the juice, expressed as \% w/v malic acid content, was determined by titration of an aliquot of $25 \mathrm{~mL}$ with $0.1 \mathrm{M} \mathrm{NaOH}$ to a $\mathrm{pH}$ endpoint of 8.1 on an automatic titrator. Fruit dry matter percentage was also determined by drying a part of the homogenate in a forced air oven at $8^{\circ} \mathrm{C}$ for $72 \mathrm{~h}$.

\section{Analysis of Aluminum and Mineral Nutrient Concentrations in Plant Tissues}

The dried plant tissues: leaf, stem, fruit, and root tissues were ground in a Wiley mill to pass through a 20 -mesh screen, then $0.5 \mathrm{~g}$ samples were analyzed for the following macro- micronutrients and toxic element: N, P, K, Ca, Mg, Fe, Mn, Zn, B, and Al. Nitrogen (total N) concentration in the four plant tissues was determined after mineralization with sulfuric acid $\left(\mathrm{H}_{2} \mathrm{SO}_{4}\right.$, 96\%, Carlo Erba Reagents, Cornaredo, Milan, Italy) in the presence of potassium sulfate $\left(\mathrm{K}_{2} \mathrm{SO}_{4}\right)$ and a low concentration of copper $(\mathrm{Cu})$ according to the Kjeldahl method (Bremner, 1965). Phosphorus, $\mathrm{K}, \mathrm{Ca}, \mathrm{Mg}, \mathrm{Fe}, \mathrm{Mn}, \mathrm{Zn}, \mathrm{B}$, and $\mathrm{Al}$ were determined by dry ashing at $400^{\circ} \mathrm{C}$ for $24 \mathrm{~h}$, dissolving the ash in $\mathrm{HNO}_{3}(1: 20$ $\mathrm{w} / \mathrm{v}$ ) and assaying the solution obtained using an inductively coupled plasma emission spectrophotometer (ICP Iris, Thermo Optek, Milan, Italy; Karla, 1998).

\section{SPAD Index Measurement}

One day before the end of Experiment 2 the Soil Plant Analysis Development (SPAD index), a non-destructive and indirect measurement of leaf chlorophyll content, was measured on the fully expanded leaves by means of a portable chlorophyll meter SPAD-502 (Konica-Minolta corporation, Ltd., Osaka, Japan). Measurements were made at the central point of the leaflet between the midrib and the leaf margin. Fifteen leaves were randomly measured and averaged to a single SPAD value for each treatment.

\section{Determination of Electrolyte Leakage}

At the same date of the SPAD index measurement, the membrane integrity in leaves was measured in terms of electrolyte leakage as described by Lutts et al. (1995). Briefly, 10 pieces of equalsized leaves $(10 \times 10 \mathrm{~mm})$ collected from four plants per plot were placed in individual vials containing $10 \mathrm{ml}$ of distilled water. The vials were incubated at room temperature $\left(25^{\circ} \mathrm{C}\right)$ for $24 \mathrm{~h}$ with continuously shaking and the initial electrical conductivity $\left(\mathrm{EC}_{1}\right)$ of the bathing solution was measured using a conductivity meter (HI991301; Hanna Instruments, Padova, Italy). To measure the total electrolytes released from leaf tissues, vials were then autoclaved at $120^{\circ} \mathrm{C}$ for $20 \mathrm{~min}$ and cooled at $25^{\circ} \mathrm{C}$ to obtain the final electrical conductivity $\left(\mathrm{EC}_{2}\right)$. The $\mathrm{EL}$ was calculated using the following formula: $\mathrm{EL}$ $(\%)=\left(\mathrm{EC}_{1} / \mathrm{EC}_{2}\right) \times 100$.

\section{Statistical Analysis}

All experimental data were subjected to a two-way ANOVA using the SPSS software package (SPSS, 2001). When ANOVA indicated that either nutrient solution or graft combination or their interaction was significant, mean separation was performed using the Duncan's multiple range test at $p=0.05$ on each of the significant variables measured. 


\section{RESULTS}

\section{Growth Response and Leaf Symptoms}

In Experiment 1, shoot and root dry mass of cucumber plants were significantly $(p<0.01)$ affected by nutrient solution and grafting combination interaction (data not shown). Shoot dry mass at $\mathrm{pH} 3.5$ in non-grafted and grafted plants was decreased by 26 and $25 \%$ over the $\mathrm{pH} 6.0$ treatment (Figure 1A). Moreover, shoot dry mass was reduced by 67 and $58 \%$ over the $\mathrm{pH} 6.0$ treatment at $\mathrm{pH} 3.5+1.5 \mathrm{mM}$ $\mathrm{Al}$ in non-grafted and rootstock-grafted plants, and further decreased by 84 and $76 \%$ at $\mathrm{pH} 3.5+3.0 \mathrm{mM} \mathrm{Al}$ (Figure 1A). Similarly, root dry mass declined at $\mathrm{pH} 3.5+1.5 \mathrm{mM} \mathrm{Al}$ and especially at $\mathrm{pH} 3.5+3.0 \mathrm{mM} \mathrm{Al}$, however, less in rootstockgrafted plants (Figure 1B). Plant growth traits in particular plant height, leaf area and number were significantly $(p<$ 0.01 ) affected by nutrient solution and grafting combination interaction (data not shown). The biometric plant traits decreased under acidity and $\mathrm{Al}$ concentration especially at $\mathrm{pH}$ $3.5+3.0 \mathrm{mM} \mathrm{Al}$ (data not shown), however, the reduction in plant growth was less pronounced in rootstock-grafted plants (Figure 2). The most evident symptom of adverse low $\mathrm{pH}$ conditions (i.e., acidity) is a yellowing between leaf veins giving the leaves a "marbled appearance," indicating magnesium deficiency. These symptoms recorded after 14 days in plants grafted onto pumpkin rootstock were less pronounced than those observed in the non-grafted plants (Figure 3).

In Experiment 2, shoot and root dry mass at the end of the growing season were significantly affected by nutrient solution, grafting combination, and their interactions, whereas the root-to-shoot ratio (R/S) was significantly influenced by both main factors (Table 1). For instance, the shoot dry mass was decreased by 30,25 , and $20 \%$ over control at low adverse $\mathrm{pH}$ (3.5) treatment in non-grafted $\mathrm{E}, \mathrm{E} / \mathrm{F}$, and $\mathrm{E} / \mathrm{C}$, and strongly decreased by 77,73 , and $66 \%$ at $\mathrm{pH} 3.5+\mathrm{Al}$ (Table 1 ). Consistent with the shoot dry mass, the root dry weight of cucumber plants decreased by 16,11 , and $8 \%$ at $\mathrm{pH} 3.5$ in $\mathrm{E}, \mathrm{E} / \mathrm{F}$, and $\mathrm{E} / \mathrm{C}$, respectively and decreased substantially by 65,48 , and $36 \%$ at $\mathrm{pH} 3.5+\mathrm{Al}$ (Table 1). The highest $\mathrm{R} / \mathrm{S}$ ratio was recorded at $\mathrm{pH} 3.5+\mathrm{Al}$ compared to $\mathrm{pH} 6.0$ and $\mathrm{pH} 3.5$ treatments, whereas among grafting combination the $\mathrm{E} / \mathrm{C}$ combination exhibited the highest $\mathrm{R} / \mathrm{S}$ ratios (Table $\mathbf{1}$ ).

\section{Marketable Yield and Yield Components}

In grafted and non-grafted plants, the marketable yield diminished in response to a decrease of the nutrient solution $\mathrm{pH}$ with more adverse effects at $\mathrm{pH} 3.5+\mathrm{Al}$ (Table 2). The reduced marketable yield was mostly caused by a reduced number of fruits per plant and mean weight (Table 2). Moreover, at $\mathrm{pH} 3.5$ and $\mathrm{pH}$ $3.5+\mathrm{Al}$, the percentage of yield reduction in comparison to the pH 6.0 treatment was lower in E/C (25 and 71\%, respectively) than in E/F (27 and 79\%, respectively) and non-grafted plants (32 and 81\%, respectively; Table 2). Under Al toxicity conditions, plants of $\mathrm{E} / \mathrm{C}$ had the highest marketable fruit yield (+50\%) compared to those at $\mathrm{E}$ and $\mathrm{E} / \mathrm{F}$ combinations (Table 2). The relatively low yield of non-grafted and E/F plants at $\mathrm{pH} 3.5+$

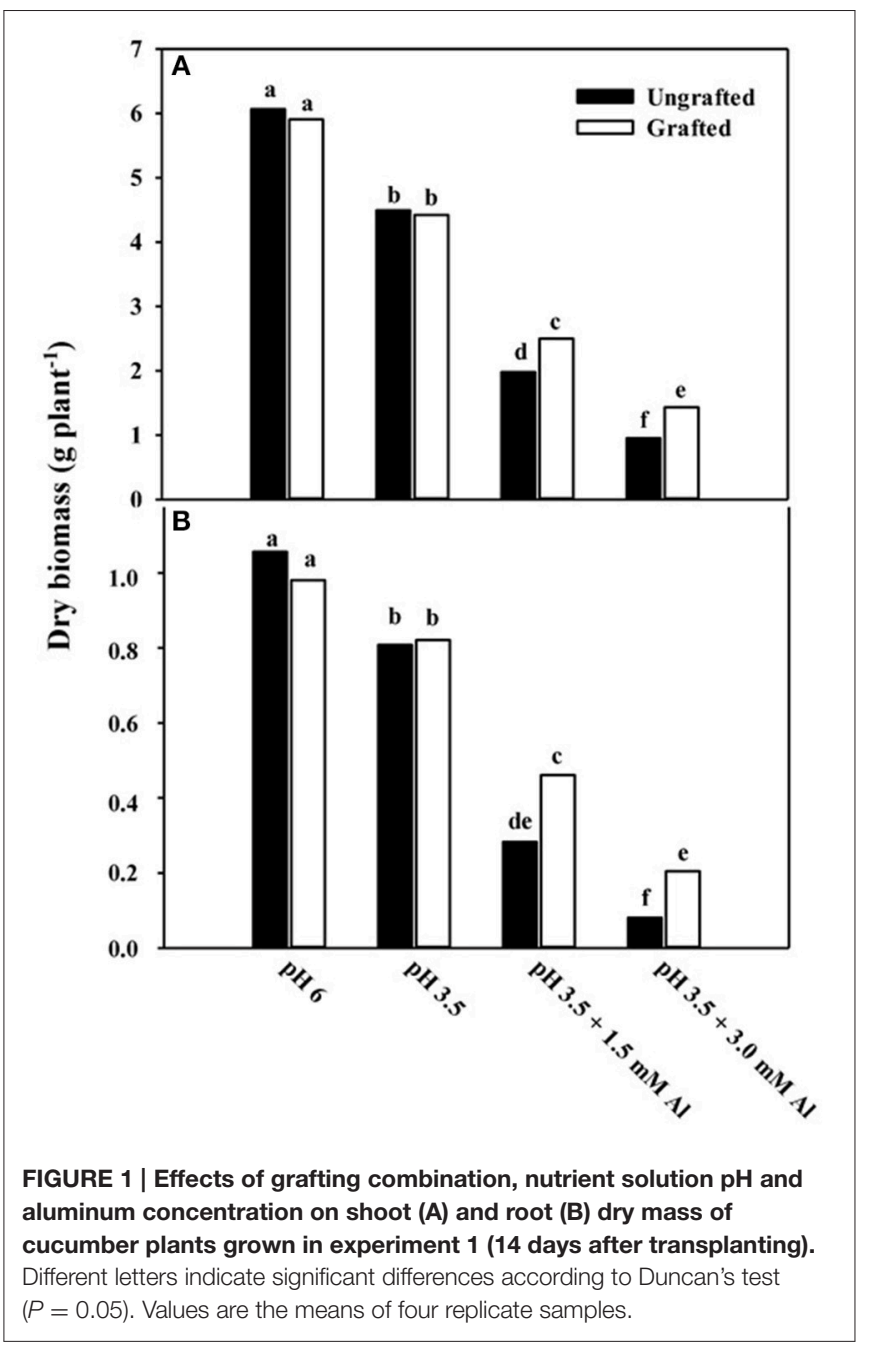

Al was attributed to a reduction in the fruit mean weight and not to a change in the number of fruit per plant (Table 2).

\section{Fruit Quality}

No significant changes were observed for titratable acidity (Table 3). The fruit SI was only influenced by nutrient solution $\mathrm{pH}$ and $\mathrm{Al}$ concentration with the highest values observed in cucumbers treated with $\mathrm{pH} 3.5+\mathrm{Al}$ compared to $\mathrm{pH} 3.5$ and $\mathrm{pH} 6.0$ treatments (Table 3). Under $\mathrm{pH}$ 3.5 and $\mathrm{Al}$ toxicity, the fruit firmness, dry matter, and total soluble solid contents decreased, but they were not significantly affected by the grafting onto figleaf gourd or pumpkin (Table 3). Moreover, when averaged over nutrient solution $\mathrm{pH}$ and $\mathrm{Al}$ concentration the highest fruit dry matter content was recorded with $\mathrm{E} / \mathrm{F}$, followed by $\mathrm{E} / \mathrm{C}$ combination, whereas the lowest values were observed with non-grafted plants.

\section{Aluminum Uptake and Distribution}

$\mathrm{Al}$ treatment increased $\mathrm{Al}$ concentration in leaves, stems, and roots but did not affect it in fruits (Table 4). The partitioning 


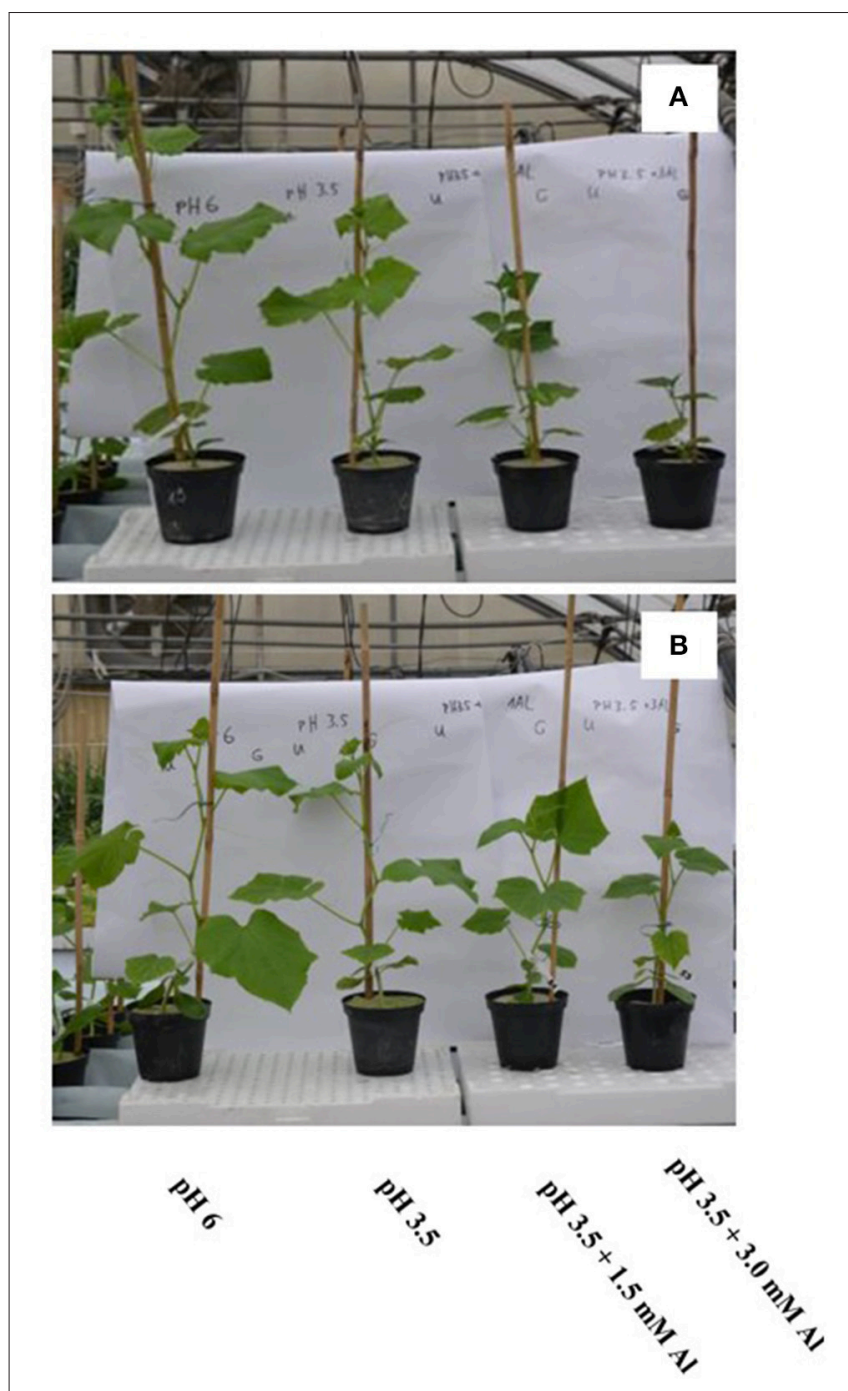

FIGURE 2 | Effects of nutrient solution $\mathrm{pH}$ and aluminum concentration on non-grafted (A) and grafted (B) cucumber plants in experiment 1 (14 days after transplanting).

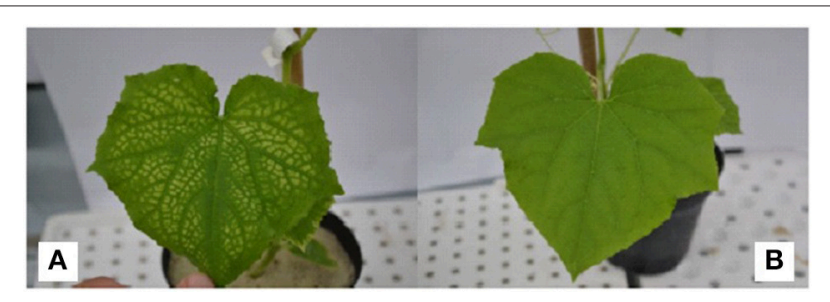

FIGURE 3 | Fully expanded leaves of non-grafted (A) and grafted (B) cucumber plants grown in experiment 1 (14 days after transplanting) and treated with a nutrient solution at $\mathrm{pH}$ 3.5.

of $\mathrm{Al}$ within the plant tissues was in the following order: roots $>$ leaves $>$ stems $>$ fruits. The highest shoot (leaf and stem) and root $\mathrm{Al}$ concentrations were observed in cucumber plants treated with $\mathrm{pH} 3.5+\mathrm{Al}$ (Table 4). There was a marked
TABLE 1 | Effects of grafting combination, nutrient solution $\mathrm{pH}$, and aluminum concentration on shoot and root biomass dry weight, and on the root-to-shoot ratio (R/S) of cucumber plants grown in experiment 2.

\begin{tabular}{|c|c|c|c|c|}
\hline Solution & $\begin{array}{l}\text { Graft } \\
\text { combination }\end{array}$ & $\begin{array}{c}\text { Shoot } \\
\left(\text { g plant }^{-1}\right)\end{array}$ & $\begin{array}{c}\text { Root } \\
\left(\text { g plant }^{-1}\right)\end{array}$ & $\mathrm{R} / \mathrm{S}$ \\
\hline \multirow[t]{4}{*}{ pH 6.0} & $E$ & 101.1a & $6.3 a$ & 0.06 \\
\hline & $E / F$ & $96.0 \mathrm{a}$ & $5.6 a b$ & 0.06 \\
\hline & $E / C$ & $97.8 \mathrm{a}$ & $6.4 \mathrm{a}$ & 0.07 \\
\hline & Mean & $98.3 a$ & $6.1 \mathrm{a}$ & $0.06 b$ \\
\hline \multirow[t]{4}{*}{ pH 3.5} & $E$ & 70.7c (30) & $5.3 b$ & 0.07 \\
\hline & $E / F$ & $72.3 c(25)$ & $5.0 \mathrm{bc}$ & 0.07 \\
\hline & E/C & $77.8 \mathrm{~b}(20)$ & $5.9 a b$ & 0.08 \\
\hline & Mean & $73.6 b$ & $5.4 b$ & $0.07 b$ \\
\hline \multirow[t]{4}{*}{$\mathrm{pH} 3.5+\mathrm{Al}$} & $E$ & $23.2 \mathrm{e}(77)$ & $2.2 \mathrm{~d}$ & 0.09 \\
\hline & $E / F$ & $24.7 e(73)$ & $2.9 d$ & 0.12 \\
\hline & $\mathrm{E} / \mathrm{C}$ & 33.6d (66) & $4.1 \mathrm{c}$ & 0.12 \\
\hline & Mean & $27.2 \mathrm{c}$ & $3.1 \mathrm{c}$ & $0.11 \mathrm{a}$ \\
\hline \multicolumn{5}{|c|}{ SIGNIFICANCE } \\
\hline \multicolumn{2}{|l|}{ Solution (S) } & 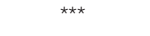 & 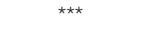 & 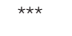 \\
\hline \multicolumn{2}{|c|}{ Graft combination (G) } & $\star \star$ & * & * \\
\hline \multicolumn{2}{|l|}{$S \times G$} & $\star$ & $\star \star$ & ns \\
\hline
\end{tabular}

E, cucumber hybrid "Ekron" (Cucumis sativus L.); E/F, "Ekron" grafted onto figleaf gourd rootstock (Cucurbita ficifolia Bouché); E/C, "Ekron" grafted onto squash hybrid rootstock "P360" (Cucurbita maxima Duch. × Cucurbita moschata Duch.).

Values are the means of four replicate samples. The percentage of reduction in solution treatments having $\mathrm{pH} 3.5$ and $\mathrm{pH} 3.5+$ Al with respect to the solution treatment having pH 6.0 (control) are reported in parenthesis.

Means within columns separated using Duncan's multiple range test, $P=0.05$.

ns., ${ }^{\star},{ }^{* \star},{ }^{\star \star \star}$ Nonsignificant or significant at $P<0.05,0.01$, or 0.001 , respectively.

influence of grafting combination on the accumulation of $\mathrm{Al}$ in aerial vegetative plant parts, whereas no statistical effects were observed in fruits and roots. Particularly, the accumulation of $\mathrm{Al}$ in leaf tissue at $\mathrm{pH} 3.5+\mathrm{Al}$, with respect to $\mathrm{pH} 6.0$, was significantly lower in E/C plants (22\%), in comparison to $\mathrm{E} / \mathrm{F}$ and non-grafted plants (72 and $87 \%$, respectively).

\section{Mineral Composition and Partitioning}

A different pattern of macronutrient accumulation and distribution in plant tissues was detected as a function of nutrient solution and grafting combination (Table 5). The concentration of $\mathrm{N}$ in leaf and fruit tissues were negatively affected by decreasing $\mathrm{pH}$ and the addition of $0.75 \mathrm{mM} \mathrm{Al}$ in the nutrient solution, while it remained unaffected in stems, fruits, and roots as compared with $\mathrm{pH} 6.0$ (Table 5). Under Al stress conditions $\mathrm{E} / \mathrm{C}$ plants markedly had higher $\mathrm{N}$ in their leaves than $\mathrm{E} / \mathrm{F}$ and non-grafted plants (Table 5). Decreasing the $\mathrm{pH}$ from 6.0 to 3.5 in the nutrient solution and the further addition of Al significantly decreased $\mathrm{P}$ concentration in stems, fruits and roots (Table 5). The concentration of $\mathrm{P}$ in roots was lower in non-grafted than grafted plants in both treatments mentioned before (Table 5).

The mean $\mathrm{K}$ concentration of the grafting combinations in stems and fruits decreased in both treatments $(\mathrm{pH}$ and $\mathrm{pH}+\mathrm{Al})$, 
TABLE 2 | Effects of grafting combination, nutrient solution $\mathrm{pH}$, and aluminum concentration on marketable fruit yield, marketable fruit mean weight, and number of cucumber plants grown in experiment 2.

\begin{tabular}{|c|c|c|c|c|}
\hline \multirow[t]{2}{*}{ Solution } & \multirow{2}{*}{$\begin{array}{l}\text { Graft } \\
\text { combination }\end{array}$} & \multirow{2}{*}{$\begin{array}{l}\text { Yield (kg } \\
\text { plant }^{-1} \text { ) }\end{array}$} & \multicolumn{2}{|c|}{ Fruit } \\
\hline & & & $\begin{array}{c}\text { Number } \\
\text { (n. plant }{ }^{-1} \text { ) }\end{array}$ & $\begin{array}{c}\text { Mean weight } \\
\text { (g fruit }^{-1} \text { ) }\end{array}$ \\
\hline \multirow[t]{4}{*}{ pH 6.0} & $E$ & $4.04 a$ & $12.5 \mathrm{a}$ & 323.2 \\
\hline & $E / F$ & $3.91 a$ & $12.4 \mathrm{a}$ & 315.3 \\
\hline & $E / C$ & $3.90 a$ & $12.1 \mathrm{a}$ & 322.3 \\
\hline & Mean & $3.95 a$ & $12.3 a$ & $320.3 a$ \\
\hline \multirow[t]{4}{*}{ pH 3.5} & $E$ & 2.73c (32) & $8.6 b$ & 317.4 \\
\hline & $E / F$ & 2.85bc (27) & $9.0 b$ & 316.7 \\
\hline & $\mathrm{E} / \mathrm{C}$ & $2.94 b(25)$ & $8.5 b$ & 345.9 \\
\hline & Mean & $2.84 b$ & $8.7 b$ & $326.7 a$ \\
\hline \multirow[t]{4}{*}{$\mathrm{pH} 3.5+\mathrm{Al}$} & $E$ & $0.77 e(81)$ & $3.0 d$ & 256.7 \\
\hline & $E / F$ & 0.80 e (79) & $3.8 c$ & 210.5 \\
\hline & $E / C$ & $1.17 d(71)$ & $4.1 \mathrm{c}$ & 285.4 \\
\hline & Mean & $0.91 \mathrm{c}$ & $3.6 c$ & $250.9 b$ \\
\hline \multicolumn{5}{|c|}{ SIGNIFICANCE } \\
\hline Solution (S) & & 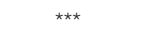 & $\star \star \star$ & 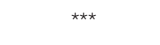 \\
\hline Graft combin & tion (G) & ns & ns & $*$ \\
\hline$S \times G$ & & $\star \star *$ & * & ns \\
\hline \multicolumn{5}{|c|}{ 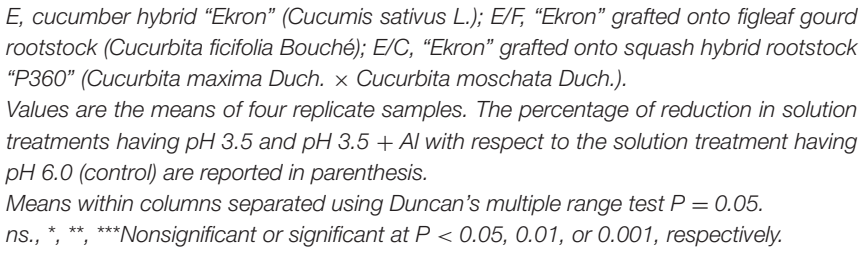 } \\
\hline
\end{tabular}

more detrimental when $\mathrm{Al}$ was supplied compared with only $\mathrm{pH}$ 3.5 (Table 5). Comparing the grafting treatments, the lowest $\mathrm{K}$ concentration was found in E/F (Table 5). The Ca concentration was also significantly affected by the low $\mathrm{pH}$ in the nutrient solution and the addition of $\mathrm{Al}$ but compared with $\mathrm{K}$ not in the fruits but in the roots. At $\mathrm{pH} 3.5+\mathrm{Al}$ the leaves and fruits had significantly lower Ca concentration in comparison to those observed at pH 3.5 and control treatment (Table 5). Moreover, the concentration of $\mathrm{Ca}$ in all plant tissues (leaf, stem, fruit, and root) was higher in $\mathrm{E} / \mathrm{C}$ than in $\mathrm{E} / \mathrm{F}$ and in non-grafted plants.

Decreasing the $\mathrm{pH}$ and the addition of $\mathrm{Al}$ in the nutrient solution decreased significantly the $\mathrm{Mg}$ concentration in leaves, stems, and roots especially under $\mathrm{Al}$ stress. The concentration of $\mathrm{Mg}$ in leaves of Al-treated plants was significantly affected by the grafting combination with values recorded for $\mathrm{E} / \mathrm{C}$ plants being higher than E/F and non-grafted plants. Similarly to leaves, the $\mathrm{Mg}$ concentration in roots was significantly higher in $\mathrm{E} / \mathrm{C}$ than in other grafting combinations (Table 5).

The effect of low $\mathrm{pH}$ and Al-supply on tissue micronutrient concentrations was highly significant (Table 6). The concentration of $\mathrm{Fe}$ in leaf tissue decreased in both stressed plant treatments with the lowest values recorded in non-grafted
TABLE 3 | Effects of grafting combination, nutrient solution $\mathrm{pH}$, and aluminum concentration on fruit shape index (SI), firmness, dry matter content (DMC), total soluble solids (TSS) content, juice $\mathrm{pH}$, and titratable acidity (TA) of cucumber fruits grown in experiment 2 .

\begin{tabular}{|c|c|c|c|c|c|c|c|}
\hline Solution & $\begin{array}{l}\text { Graft } \\
\text { combination }\end{array}$ & SI & $\begin{array}{l}\text { Firmness } \\
\left(\mathrm{N} \mathrm{cm}^{-2}\right)\end{array}$ & $\begin{array}{l}\text { DMC } \\
(\%)\end{array}$ & $\begin{array}{c}\text { TSS } \\
\left({ }^{\circ} \text { brix }\right)\end{array}$ & $\mathrm{pH}$ & $\begin{array}{l}\text { TA } \\
(\%)\end{array}$ \\
\hline \multirow[t]{4}{*}{ pH 6.0} & $E$ & 0.24 & 1.53 & 4.41 & $3.87 a$ & 6.12 & 0.11 \\
\hline & $E / F$ & 0.23 & 1.56 & 4.34 & $3.63 a$ & 6.12 & 0.09 \\
\hline & $E / C$ & 0.23 & 1.52 & 4.24 & $3.70 a$ & 6.18 & 0.09 \\
\hline & Mean & $0.23 b$ & $1.54 \mathrm{a}$ & $4.33 a$ & $3.74 a$ & $6.14 \mathrm{a}$ & 0.10 \\
\hline \multirow[t]{4}{*}{ pH 3.5} & $E$ & 0.23 & 1.32 & 3.43 & $2.92 d$ & 5.81 & 0.08 \\
\hline & $E / F$ & 0.23 & 1.37 & 3.70 & $3.14 \mathrm{c}$ & 5.90 & 0.08 \\
\hline & $E / C$ & 0.23 & 1.60 & 3.77 & $3.17 \mathrm{c}$ & 5.97 & 0.11 \\
\hline & Mean & $0.23 b$ & $1.43 a b$ & $3.63 b$ & $3.08 b$ & $5.89 b$ & 0.09 \\
\hline \multirow[t]{4}{*}{$\mathrm{pH} 3.5+\mathrm{Al}$} & $E$ & 0.27 & 1.29 & 3.34 & $3.22 \mathrm{c}$ & 5.52 & 0.09 \\
\hline & $E / F$ & 0.28 & 1.23 & 4.34 & $3.53 \mathrm{bc}$ & 5.28 & 0.10 \\
\hline & $E / C$ & 0.24 & 1.43 & 3.78 & $3.09 \mathrm{~cd}$ & 5.61 & 0.08 \\
\hline & Mean & $0.26 a$ & $1.31 b$ & $3.82 b$ & $3.28 b$ & $5.47 \mathrm{c}$ & 0.09 \\
\hline \multicolumn{8}{|c|}{ SIGNIFICANCE } \\
\hline \multicolumn{2}{|l|}{ Solution (S) } & 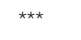 & * & 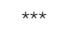 & $\star \star \star$ & 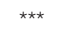 & ns \\
\hline \multicolumn{2}{|c|}{ Graft combination (G) } & ns & ns & * & ns & ns & ns \\
\hline \multicolumn{2}{|l|}{$S \times G$} & ns & ns & ns & $\star \star$ & ns & ns \\
\hline
\end{tabular}

E, cucumber hybrid "Ekron" (Cucumis sativus L.); E/F, "Ekron" grafted onto figleaf gourd rootstock (Cucurbita ficifolia Bouché); E/C, "Ekron" grafted onto squash hybrid rootstock "P360" (Cucurbita maxima Duch. × Cucurbita moschata Duch.).

Values are the means of four replicate samples.

Means within columns separated using Duncan's multiple range test, $P=0.05$. ns., ${ }^{*}{ }^{* \star},{ }^{* \star \star}$ Nonsignificant or significant at $P<0.05,0.01$, or 0.001 , respectively.

plants supplied with $\mathrm{pH} 3.5+\mathrm{Al}$. Concerning the grafting combination, the lowest concentration of $\mathrm{Fe}$ in the roots was observed in E/F plants (Table 6). Moreover, the concentrations of $\mathrm{Mn}$ (in all plant tissues), $\mathrm{Zn}$ (fruits and roots), and $\mathrm{B}$ (leaves) declined with increasing acidity and $\mathrm{Al}$ concentration in the nutrient solution. Finally, when averaged over nutrient solution, the $\mathrm{Mn}$ and $\mathrm{Zn}$ concentrations in all plant tissues were significantly higher in E/C as compared with other grafting combinations (Table 6).

\section{Leaf Area, SPAD Index, and Electrolyte Leakage}

The total leaf area and electrolyte leakage were significantly affected by grafting combination, nutrient solution and their interaction, whereas the SPAD index was significantly influenced by grafting combination and nutrient solution with no interaction of these two factors (Table 7). The total leaf area decreased in response to a decrease of nutrient solution $\mathrm{pH}$, with more detrimental at $\mathrm{pH} 3.5+\mathrm{Al}$ (Table 7). However, comparing $\mathrm{pH} 3.5+\mathrm{Al}$ with $\mathrm{pH} 6$, the leaf area was less reduced in $\mathrm{E} / \mathrm{C}(46 \%)$ than in $\mathrm{E} / \mathrm{F}(61 \%)$ and non-grafted plants (68\%; Table 7). The highest mean SPAD index of the grafting treatments was recorded at $\mathrm{pH} 6.0$, while it was significantly lower at $\mathrm{pH} 3.5+\mathrm{Al}$. The chlorophyll content recorded in grafted plants (avg. 40.8) was higher by $7 \%$ compared with ungrafted 
TABLE 4 | Effects of grafting combination, nutrient solution $\mathrm{pH}$, and aluminum concentration on Al distribution in leaf, stem, fruit, and root tissues of cucumber plants grown in experiment 2.

\begin{tabular}{|c|c|c|c|c|c|}
\hline \multirow[t]{2}{*}{ Solution } & \multirow[t]{2}{*}{ Graft combination } & \multicolumn{4}{|c|}{$\mathrm{Al}\left(\mathrm{mg} \mathrm{kg}^{-1} \mathrm{DW}\right)$} \\
\hline & & Leaves & Stems & Fruits & Roots \\
\hline \multirow[t]{4}{*}{ pH 6.0} & $E$ & $85.7 \mathrm{c}$ & 10.6 & 6.2 & 263.7 \\
\hline & $E / F$ & $80.5 c$ & 13.7 & 6.2 & 271.1 \\
\hline & $E / C$ & $87.2 \mathrm{c}$ & 7.8 & 6.0 & 236.0 \\
\hline & Mean & $84.5 b$ & $10.7 \mathrm{~b}$ & 6.1 & $257.0 \mathrm{~b}$ \\
\hline \multirow[t]{4}{*}{$\mathrm{pH} 3.5$} & $\mathrm{E}$ & $90.5 \mathrm{c}$ & 10.1 & 6.1 & 303.4 \\
\hline & $E / F$ & $88.0 \mathrm{c}$ & 10.6 & 7.3 & 468.7 \\
\hline & $\mathrm{E} / \mathrm{C}$ & $93.0 \mathrm{c}$ & 9.6 & 7.5 & 734.0 \\
\hline & Mean & $90.5 b$ & $10.1 b$ & 6.9 & $502.1 \mathrm{k}$ \\
\hline \multirow[t]{4}{*}{$\mathrm{pH} 3.5+\mathrm{Al}$} & $E$ & 160.0a & 22.5 & 7.7 & 7697.0 \\
\hline & $\mathrm{E} / \mathrm{F}$ & $138.3 b$ & 19.8 & 10.0 & 6575.7 \\
\hline & $\mathrm{E} / \mathrm{C}$ & $106.4 \mathrm{c}$ & 16.6 & 7.1 & 5395.8 \\
\hline & Mean & $134.9 a$ & $19.6 a$ & 8.9 & 6556.1 \\
\hline \multicolumn{6}{|c|}{ SIGNIFICANCE } \\
\hline \multicolumn{2}{|l|}{ Solution (S) } & $\star \star \star \star$ & $\star \star \star \star$ & ns & $\star \star \star$ \\
\hline \multicolumn{2}{|c|}{ Graft combination (G) } & * & * & ns & ns \\
\hline \multicolumn{2}{|l|}{$S \times G$} & $\star \star *$ & ns & ns & ns \\
\hline
\end{tabular}

E, cucumber hybrid "Ekron" (Cucumis sativus L.); E/F, "Ekron" grafted onto figleaf gourd rootstock (Cucurbita ficifolia Bouché); E/C, "Ekron" grafted onto squash hybrid rootstock "P360" (Cucurbita maxima Duch. × Cucurbita moschata Duch.).

Values are the means of four replicate samples.

Means within columns separated using Duncan's multiple range test, $P=0.05$.

ns., ${ }^{*},{ }^{* *},{ }^{* \star *}$ Nonsignificant or significant at $P<0.05,0.01$, or 0.001 , respectively.

plants (38.3). Finally, the highest electrolyte leakage values were recorded in E/C and non-grafted plants supplied with $\mathrm{pH} 3.5+$ $\mathrm{Al}$ (Table 7).

\section{DISCUSSION}

Under acidic soils, reduced plant growth and consequently productivity are induced by different morphological, biochemical, and physiological alterations (Kochian et al., 2015; Rengel et al., 2015). Rapid damage and growth inhibition of the root system is the primary symptom of Al toxicity at concentrations in the $\mu \mathrm{M}$ range, which may be associated with interference in the elongation and division of meristematic cells (Rengel and Zhang, 2003; Kochian et al., 2004; Sivaguru et al., 2013). This interference reduces the absorption of water and nutrients, thus conditioning stress sensitivity and limiting plant biomass production (Inostroza-Blancheteau et al., 2012). In agreement, in both experiments a significant reduction in root, shoot biomass, and yield was observed at low $\mathrm{pH}$ (3.5) and even more, when $\mathrm{Al}$ was added (Figure 1; Tables 1, 2), suggesting that these two stresses differ in their inhibition on plant growth (Rangel et al., 2005; Bose et al., 2010). Moreover, the reduction in plant biomass production depended on the $\mathrm{Al}$ concentration. The constrained crop growth and fruit yield observed under $\mathrm{pH} 3.5$ and under $\mathrm{pH} 3.5+\mathrm{Al}$ has been reported in previous open field and greenhouse studies on tomato (Nogueirol et al., 2015) and zucchini squash (Rouphael et al., 2015). Nevertheless, decreasing $\mathrm{pH}$ and increasing $\mathrm{Al}$ concentration in the nutrient solution improved fruit quality characteristics such as fruit DM and TSS contents (Table 3). These phenomena have been found before for zucchini and explained by a decrease in water accumulation by the fruit without any effect on the synthesis and accumulation of organic solutes (Rouphael et al., 2012, 2015).

When cucumber cv. Ekron were grafted onto pumpkin rootstock "P360" compared with non-grafted and grafted onto figleaf gourd, the suppression of growth and production suppression under Al-supply was mitigated indicating a genetic diversity in Al-tolerance among cucumber rootstocks. The Altolerance of cucumber grafted onto pumpkin "P360" may be attributed to a greater uptake and translocation of $\mathrm{K}, \mathrm{Ca}$, $\mathrm{Mg}, \mathrm{Mn}$, and $\mathrm{Zn}$ to the aerial parts (leaves and stems). The enhanced nutritional status and abiotic stress-tolerance of grafted vegetables has often been associated with an enlarged and more vigorous root system (Colla et al., 2010c; Savvas et al., 2010). The root is the first organ sensing abiotic stresses in soil or substrates, such as acidity and $\mathrm{Al}$ toxicity. Therefore, the enhanced root growth (Table 1), length, and density (data not shown) of a pumpkin compared with a cucumber rootstock are important aspects for cucumbers cultivated in acidic conditions with or without Al toxicity.

$\mathrm{Al}$ accumulates in the epidermis and in the outer cortex of the root (Delhaize et al., 1993; Ryan et al., 2001). Many studies demonstrated that the major fraction of absorbed $\mathrm{Al}$ (30-90\% of total Al) is localized in the apoplast (Yang et al., 2000; Ryan et al., 2001; Pereira et al., 2010). In Experiment 2, Al concentration in the root tissues was 50 times higher than in the cucumber leaves and even higher than in stems or fruits (Table 4). This indicates that the endodermis of roots represents a barrier to the transport of Al to the shoot (Dogan et al., 2014). Interestingly, this ratio was independent of the type of rootstock used although the absolute $\mathrm{Al}$ concentration differed between grafted and nongrafted root systems. The different $\mathrm{Al}$ accumulation in plant tissues highly depends on the mechanism (exclusion or internal tolerance) used by plants to confer tolerance to Al toxicity (Delhaize and Ryan, 1995; Kochian, 1995). Our results showed that $\mathrm{Al}$ concentration in cucumber roots was similar between grafted (E/C and E/F) and non-grafted plants grown under Alstress (Table 4). This indicates that neither the figleaf gourd nor the pumpkin rootstocks were able to exclude $\mathrm{Al}$ from the root apex by exudation of organic acids (citrate, malate, and oxalate) into the rhizosphere (Brunner and Sperisen, 2013). On the other hand, the lowest $\mathrm{Al}$ accumulation in leaves with $\mathrm{pH}$ $3.5+\mathrm{Al}$ was recorded in the $\mathrm{E} / \mathrm{C}$ combination compared to the other grafting combinations (Table 4) indicating that another mechanism was involved in mitigating the Al toxicity effect (Barceló and Poscheinrieder, 2002; Brunner and Sperisen, 2013). It appears that grafting cucumber onto pumpkin rootstock can restrict the $\mathrm{Al}$ root-to-shoot translocation (Table 4), throughout "the sequestration of this toxic element into less sensitive parts of the plant and cell compartments (e.g., vacuoles)" (InostrozaBlancheteau et al., 2012; Brunner and Sperisen, 2013; Kochian et al., 2015). This suppression of Al uptake and translocation 


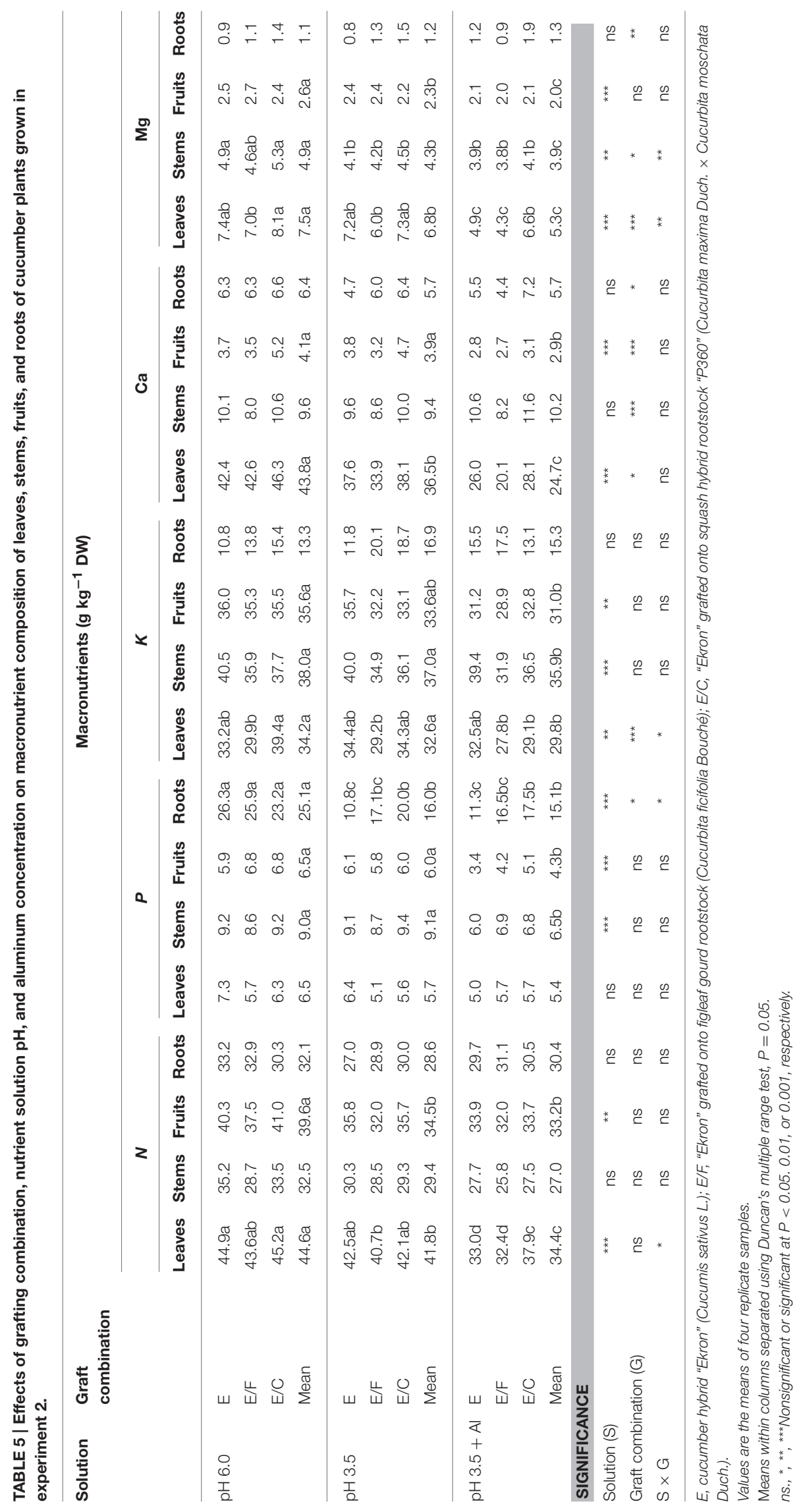


TABLE 6 | Effects of grafting combination, nutrient solution pH and aluminum concentration on micronutrient composition of leaves, stems, fruits, and roots of cucumber plants grown in experiment 2.

\begin{tabular}{|c|c|c|c|c|c|c|c|c|c|c|c|c|c|c|c|c|c|}
\hline \multirow[t]{3}{*}{ Solution } & \multirow{3}{*}{$\begin{array}{l}\text { Graft } \\
\text { combination }\end{array}$} & \multicolumn{16}{|c|}{ Micronutrients (mg kg $\left.{ }^{-1} \mathrm{DW}\right)$} \\
\hline & & \multicolumn{4}{|c|}{$\mathbf{F e}$} & \multicolumn{4}{|c|}{ Mn } & \multicolumn{4}{|c|}{$\mathrm{Zn}$} & \multicolumn{4}{|c|}{ B } \\
\hline & & Leaves & Stems & Fruits & Roots & Leaves & Stems & Fruits & Roots & Leaves & Stems & Fruits & Roots & Leaves & Stems & Fruits & Roots \\
\hline \multirow[t]{4}{*}{ pH 6.0} & $E$ & $56.5 b c$ & $30.6 c$ & 27.0 & 202.6 & 254.4 & 54.6ab & $23.4 \mathrm{C}$ & 64.2 & $48.0 \mathrm{bc}$ & 40.9 & 32.5 & 28.0 & 67.6 & 15.8 & 13.2 & 7.8 \\
\hline & $E / F$ & 73.3ab & $27.6 \mathrm{c}$ & 30.6 & 123.5 & 269.8 & $41.1 \mathrm{bc}$ & $23.7 \mathrm{c}$ & 64.0 & $32.9 d$ & 49.1 & 30.0 & 77.4 & 82.5 & 16.3 & 13.9 & 10.5 \\
\hline & $E / C$ & $62.3 b$ & $43.9 a$ & 24.8 & 202.6 & 302.3 & $63.9 a$ & $35.6 a$ & 82.6 & $65.8 a$ & 61.5 & 30.8 & 56.8 & 68.1 & 14.7 & 13.3 & 10.7 \\
\hline & Mean & 64.1 & 34.0ab & $27.4 \mathrm{a}$ & 176.2 & $262.1 \mathrm{a}$ & $53.2 \mathrm{a}$ & $27.6 a$ & $70.3 a$ & 48.9 & 50.5 & $31.1 a$ & $54.1 b$ & $72.7 a$ & 15.6 & 13.4 & 9.6 \\
\hline \multirow[t]{4}{*}{ pH 3.5} & $E$ & $59.8 b c$ & $35.9 b$ & 31.2 & 192.4 & 205.5 & 43.3bc & $26.0 \mathrm{bc}$ & 62.2 & $50.4 b$ & 53.3 & 30.3 & 29.9 & 58.3 & 14.8 & 12.7 & 11.7 \\
\hline & $E / F$ & $80.7 a$ & $39.0 a$ & 34.6 & 170.1 & 219.3 & $48.1 b$ & $22.2 \mathrm{C}$ & 66.1 & $30.9 d$ & 49.7 & 27.6 & 63.4 & 57.9 & 16.3 & 13.4 & 13.7 \\
\hline & $E / C$ & 72.9ab & $38.8 a$ & 29.2 & 176.7 & 248.5 & $48.1 b$ & $30.5 b$ & 71.4 & $55.5 b$ & 81.8 & 32.7 & 72.1 & 59.1 & 15.4 & 11.9 & 9.3 \\
\hline & Mean & 71.1 & $37.9 a$ & $31.6 a$ & 179.7 & $212.4 b$ & $46.5 b$ & $26.2 a$ & $66.6 a$ & 45.6 & 61.6 & $30.2 a$ & $55.1 b$ & $58.4 b$ & 15.5 & 12.7 & 11.5 \\
\hline \multirow[t]{4}{*}{$\mathrm{pH} 3.5+\mathrm{Al}$} & $E$ & $48.0 \mathrm{c}$ & $31.2 \mathrm{bc}$ & 19.0 & 205.5 & 141.0 & $37.5 b$ & $15.9 d$ & 37.9 & $45.4 \mathrm{C}$ & 55.2 & 23.3 & 64.3 & 52.3 & 16.9 & 13.1 & 7.7 \\
\hline & $E / F$ & 65.8ab & $30.8 \mathrm{c}$ & 19.6 & 130.2 & 132.4 & $42.6 b c$ & $17.4 d$ & 32.1 & $47.3 c$ & 62.5 & 22.2 & 86.8 & 61.9 & 18.2 & 13.6 & 10.4 \\
\hline & $E / C$ & $82.2 a$ & $30.3 c$ & 21.1 & 208.6 & 163.3 & $47.6 b$ & $18.7 d$ & 75.2 & $50.7 \mathrm{bc}$ & 82.9 & 30.2 & 72.6 & 47.5 & 13.3 & 12.8 & 11.6 \\
\hline & Mean & 65.3 & $30.8 b$ & 19.9b & 181.4 & 136.7c & $42.6 b$ & $17.4 b$ & $48.4 b$ & 47.8 & 66.9 & $25.2 b$ & $74.6 a$ & $53.9 b$ & 16.1 & 13.1 & 9.9 \\
\hline \multicolumn{18}{|c|}{ SIGNIFICANCE } \\
\hline \multicolumn{2}{|l|}{ Solution (S) } & ns & $\star \star \star ~$ & $\star \star \star$ & ns & 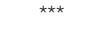 & 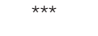 & $\star \star \star \star ~$ & * & ns & ns & $\star \star \star \star ~$ & * & 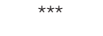 & ns & ns & ns \\
\hline \multicolumn{2}{|c|}{ Graft combination (G) } & 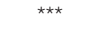 & * & ns & $\star \star$ & $\star \star$ & ** & *** & * & $\star \star \star ~$ & $\star \star \star$ & *** & 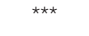 & ns & ns & ns & ns \\
\hline \multicolumn{2}{|l|}{$S \times G$} & * & * & ns & ns & ns & * & * & ns & * & ns & ns & ns & ns & ns & ns & ns \\
\hline
\end{tabular}

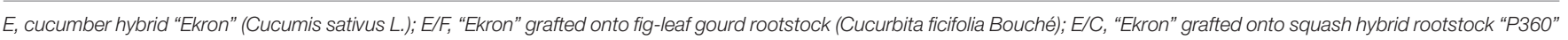
(Cucurbita maxima Duch. $\times$ Cucurbita moschata Duch.).

Values are the means of four replicate samples.

Means within columns separated using Duncan's multiple range test, $P=0.05$.

ns., ${ }^{*},{ }^{\star \star},{ }^{* \star \star}$ Nonsignificant or significant at $P<0.05 .0 .01$, or 0.001 , respectively.

to shoots of grafted plants is consistent with previous reports indicating that appropriate rootstocks of cucurbitaceous and solanaceous species may limit the uptake of toxic elements and heavy metals (Edelstein et al., 2005; Rouphael et al., 2008a; Kumar et al., 2015b). Authors show that grafting annual fruit crops, such as melon, cucumber, and tomato onto vigorous rootstocks (i.e., pumpkin for cucurbits and "Maxifort" for tomato) may significantly restrict trace elements' ( $\mathrm{B}$ and $\mathrm{Cu}$ ) and heavy metal (Ni) concentrations in leaf and fruit tissue, thereby alleviating their detrimental effects on crop productivity and human health via the food chain (Savvas et al., 2010).

Nutrient uptake is a crucial aspect for the maintenance of homeostasis and plant growth under unfavorable soil conditions (i.e., edaphic stress; Seguel et al., 2013). Tolerance of $\mathrm{Al}$ is mostly reflected in limited alterations of macro and micronutrient's acquisition and translocation (Andrade et al., 2009). In the present study, decreasing $\mathrm{pH}$ level and increasing $\mathrm{Al}$ concentration in the nutrient solution depressed concentrations of macro- (N, P, K, Ca, and Mg) and micro-elements ( $\mathrm{Mn}$ and $\mathrm{Zn}$ ) in shoots (leaves and/or stems) and to a lesser degree in roots in both grafted and non-grafted plants (Tables 5, 6). Therefore, excessive $\mathrm{Al}$ accumulation affected uptake, translocation and accumulation of these nutrients in plant tissues, and hence was responsible for mineral imbalances and deficiencies as well as for the depression of plant growth and yield (Rouphael et al.,
2015). Studies have demonstrated that Al interferes directly with several different plasma membrane channel proteins, thus reducing the uptake of mono- and divalent cations such as $\mathrm{K}$ and Ca (Gassmann and Schroeder, 1994; Piñeros and Tester, 1995). Al-stress has been reported to reduce Ca through three mechanisms: "(1) inhibition of Ca transport via symplasm by $\mathrm{Al}$, (2) disruption of $\mathrm{Ca}$ homeostasis in cytoplasm by $\mathrm{Al}$, and (3) Ca displacement by Al from apoplasm" (Delhaize and Ryan, 1995; Kochian, 1995). In addition to the reduction in $\mathrm{K}$ and $\mathrm{Ca}$ uptake, $\mathrm{Al}$ can also decrease $\mathrm{Mg}$ uptake in aerial parts (Rengel and Robinson, 1989), as we can confirm with our current data. The competition between these two cations ( $\mathrm{Al}$ and $\mathrm{Mg}$ ) was demonstrated for membrane transporters and metal binding sites in enzymatic reactions (Rengel and Robinson, 1989; Pécsváradi et al., 2009).

However, grafted and non-grafted plants diverged in their tissue nutrient concentration in relation to acidity and $\mathrm{Al}$ toxicity. Grafting cucumber plants onto the pumpkin rootstock (E/C) increased $\mathrm{K}, \mathrm{Ca}, \mathrm{Mg}, \mathrm{Mn}$, and $\mathrm{Zn}$ in shoot and/or root (Tables 5, 6) suggesting that selecting appropriate rootstocks can maintain nutrient homeostasis under Al-stress. The lower reduction in cation uptake observed in the $\mathrm{E} / \mathrm{C}$ combination under Al-stress, could be associated to the lower inhibition of root growth and elongation since cation (especially $\mathrm{K}$ ) accumulation contributes to the expansion of cell elongation 
TABLE 7 | Effects of grafting combination, nutrient solution $\mathrm{pH}$, and aluminum concentration on final leaf area, SPAD index, and leaf electrolyte leakage of cucumber plants grown in experiment 2.

\begin{tabular}{|c|c|c|c|c|}
\hline Solution & $\begin{array}{l}\text { Graft } \\
\text { combination }\end{array}$ & $\begin{array}{c}\text { Leaf area } \\
\left(\mathrm{m}^{2} \text { plant }^{-1}\right)\end{array}$ & $\begin{array}{l}\text { SPAD } \\
\text { index }\end{array}$ & $\begin{array}{c}\text { Electrolyte } \\
\text { leakage (\%) }\end{array}$ \\
\hline \multirow[t]{4}{*}{$\mathrm{pH} 6.0$} & E & $1.24 a$ & 47.3 & $33.4 \mathrm{e}$ \\
\hline & $E / F$ & $1.11 \mathrm{a}$ & 49.1 & $35.0 \mathrm{e}$ \\
\hline & $\mathrm{E} / \mathrm{C}$ & $1.05 a b$ & 48.3 & $38.6 \mathrm{de}$ \\
\hline & Mean & $1.13 a$ & $48.2 \mathrm{a}$ & $35.7 \mathrm{c}$ \\
\hline \multirow[t]{4}{*}{ pH 3.5} & E & $0.73 c$ & 36.6 & $51.2 \mathrm{C}$ \\
\hline & $E / F$ & $0.79 \mathrm{bc}$ & 37.4 & $48.4 d$ \\
\hline & $E / C$ & $0.85 b$ & 41.0 & $42.8 d$ \\
\hline & Mean & $0.79 b$ & 38.3ab & $47.5 b$ \\
\hline \multirow[t]{4}{*}{$\mathrm{pH} 3.5+\mathrm{Al}$} & E & $0.39 \mathrm{e}$ & 31.1 & $68.3 a$ \\
\hline & $E / F$ & $0.43 e$ & 33.8 & $64.9 a$ \\
\hline & $E / C$ & $0.57 d$ & 35.2 & $61.1 \mathrm{~b}$ \\
\hline & Mean & $0.46 c$ & $33.4 \mathrm{~b}$ & $64.8 \mathrm{a}$ \\
\hline \multicolumn{5}{|c|}{ SIGNIFICANCE } \\
\hline \multicolumn{2}{|l|}{ Solution (S) } & 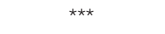 & 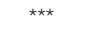 & 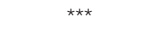 \\
\hline \multicolumn{2}{|c|}{ Graft combination (G) } & ns & $\star \star \star ~$ & ns \\
\hline \multicolumn{2}{|l|}{$S \times G$} & * & ns & $\star \star$ \\
\hline
\end{tabular}

E, cucumber hybrid "Ekron" (Cucumis sativus L.); E/F, "Ekron" grafted onto figleaf gourd rootstock (Cucurbita ficifolia Bouché); E/C, "Ekron" grafted onto squash hybrid rootstock "P360" (Cucurbita maxima Duch. × Cucurbita moschata Duch.).

Values are the means of four replicate samples.

Means within columns separated using Duncan's multiple range test, $P=0.05$.

ns., ${ }^{*},{ }^{* \star},{ }^{\star \star \star}$ Nonsignificant or significant at $P<0.05,0.01$, or 0.001 , respectively.

(Cristancho et al., 2011). Similarly, the shoot and root $\mathrm{Mg}$ concentrations were higher in $\mathrm{E} / \mathrm{C}$ compared to the other grafting combinations. It remains to be elucidated whether higher $\mathrm{Mg}$ uptake in $\mathrm{E} / \mathrm{C}$ combination is a consequence of a greater root growth and/or greater $\mathrm{Al}$ tolerance of Mg-uptake systems (Rengel et al., 2015). From above we could suggest that an efficient metabolism system exists in $\mathrm{E} / \mathrm{C}$ combination under $\mathrm{Al}$ toxicity, indicating that $\mathrm{Al}$ tolerance is correlated with enhanced mineral nutrient concentrations in plant tissues (Rouphael et al., 2015). These results are consistent with several studies (Rouphael et al., 2008a; Kumar et al., 2015a,b) reporting that rootstocks used in grafting of annual fruit crops were able to enhance the uptake of some macro- and micro-elements under heavy metal (e.g., Cd, $\mathrm{Ni}$, and $\mathrm{Cu}$ ) toxicity.

High Al concentrations in soil or substrates hamper plant development at a physiological and biochemical level, affect its photosynthetic rate, total chlorophyll content, and also inhibit electron transport in PSII (Chen, 2006; Inostroza-Blancheteau et al., 2012). This was confirmed with our measurements of the SPAD index, widely used as a non-destructive estimate of chlorophyll content. It dropped sharply in leaves of $\mathrm{Al}$ stressed non-grafted plants compared to both $\mathrm{E} / \mathrm{C}$ and $\mathrm{E} / \mathrm{F}$ plants (Table 7). This suggests the occurrence of chlorophyll degradation and early senescence, likely due to the harmful effects of reactive oxygen species on chloroplasts (Chen, 2006; Rouphael et al., 2015). Contrarily, the grafted cucumber plants in particular $\mathrm{E} / \mathrm{C}$ combination were able to maintain a higher chlorophyll content in both stress treatments, thus exhibiting the highest yield and biomass. In addition to a reduced chlorophyll content, reductions in total leaf area at low $\mathrm{pH}$ and especially at Al-supply could be caused by a premature leaf senescence and ion toxicity (Seguel et al., 2013). Maintenance of a large leaf area upon $\mathrm{Al}$ stress in $\mathrm{E} / \mathrm{C}$ combination (Table 7) may be crucial to guarantee production and translocation of photosynthates to the fruits, thus increasing the final yield in cucumber.

Adverse $\mathrm{pH}$ conditions and $\mathrm{Al}$-stress induced impairment of membrane integrity and affect all physiological activities linked to membrane functioning (Rouphael et al., 2015). This is related to the fact that Al-enhanced oxidative stress caused by an increased production of reactive oxygen species leads to lipid and protein oxidation (Boscolo et al., 2003; Jones et al., 2006). The results of Experiment 2 indicate that in cucumber the electrolyte leakage percentage (i.e., degree of cell membrane injury) was significantly increased, and depended on the nutrient solution $\mathrm{pH}$ and the $\mathrm{Al}$ concentration (Table 7). The degree of cell membrane injury induced by Al-stress has often been related to calcium concentration, an important factor in increasing structural stability of cell membrane (Borer et al., 2005). Increasing $\mathrm{Al}$ concentration in the nutrient solution reduced leaf and root calcium uptake resulting in a reduction of cell membrane integrity (Pereira et al., 2010). However, E/C plants reduced the amount of ion leakage in Al-stress treatment by improving the Ca uptake in shoot and root tissues indicating that grafting cucumber onto pumpkin rootstocks has facilitated the membrane functions (i.e., semipermeability).

\section{CONCLUSIONS}

Our findings indicate that in both grafted and non-grafted plants, agronomical, physiological, and mineral composition responses were negatively affected by acidity and $\mathrm{Al}$ concentration, with Al-stress being more phytotoxic than low $\mathrm{pH}$ treatment. The results of both experiments were able to verify our hypothesis that grafting onto suitable rootstocks (i.e., pumpkin) may limit the $\mathrm{Al}$ accumulation in the aerial parts, improve the uptake of nutrients ( $\mathrm{K}, \mathrm{Ca}, \mathrm{Mg}, \mathrm{Mn}$, and $\mathrm{Zn}$ ), enhance chlorophyll synthesis as well as the root genotypes to control the cell membrane stability; thus alleviating the impacts of adverse $\mathrm{pH}$ level and $\mathrm{Al}$ toxicity on crop productivity. These results might be useful to assist the selection of tolerant rootstocks in breeding programs particularly in acidic soils, where Al-toxicity is a major agronomic constraint.

\section{AUTHOR CONTRIBUTIONS}

YR performed the long term experiment with agronomical and physiological analysis and he was involved in writing the manuscript (Experiment 2); ER and MC performed the mineral analysis in both experiments and they collaborated in manuscript preparation; $\mathrm{MB}$ and DS were involved in the short term experiment (Experiment 1) and in manuscript preparation; GC defined the scientific hypothesis, set up the experimental protocols, made the statistical analysis of experimental data, and he was involved in the manuscript preparation. 


\section{ACKNOWLEDGMENTS}

This work was partially supported by the German-Italian Cooperation VIGONI Program in the frame of the project "The effectiveness of grafting to improve the vegetable crop

\section{REFERENCES}

Albacete, A., Martinez-Andujar, C., Martinez-Pérez, A., Thompson, A. J., Dodd, I. C., and Pérez-Alfocea, F. (2015). Unravelling rootstock $\times$ scion interactions to improve food security. J. Exp. Bot. 66, 2211-2226. doi: 10.1093/jxb/erv027

Andrade, S. A. L., Mazzafera, P., Schiavinato, M. A., and Silveira, A. P. D. (2009). Arbuscular mycorrhizal association in coffee. J. Agric. Sci. 147, 105-115. doi: $10.1017 /$ S0021859608008344

Barceló, J., and Poscheinrieder, C. (2002). Fast growth responses, root exudates, and internal detoxification as clues to the mechanisms of aluminium toxicity and resistance: a review. Environ. Exp. Bot. 48, 75-92. doi: 10.1016/S0098-8472 (02)00013-8

Borer, C. H., Schaberg, P. G., and De Hayes, D. H. (2005). Acidic mist reduces foliar membrane-associated calcium and impairs stomatal responsiveness in red spruce. Tree Physiol. 24, 929-939. doi: 10.1093/treephys/24.9.929

Boscolo, P. R. S., Menossi, M., and Jorge, R. A. (2003). Aluminium-induced oxidative stress in maize. Phytochenistry 62, 181-189. doi: 10.1016/S00319422(02)00491-0

Bose, J., Babourina, O., and Rengel, Z. (2011). Role of magnesium in alleviation of aluminium toxicity in plants. J. Exp. Bot. 62 2251-2264. doi: 10.1093/jxb/erq456

Bose, J., Babourina, O., Shabala, S., and Rengel, Z. (2010). Alumiun-dependent dynamics of ion transport in Arabidopsis: specificity of low $\mathrm{pH}$ and aluminium responses. Physiol. Plant. 139, 401-412. doi: 10.1111/j.1399-3054.2010. 01377.x

Bremner, J. M. (1965). “Total nitrogen," in Methods of Soil Analysis (Agronomy Monograph No. 9 Part 2), eds C. A. Black, D. D. Evans, I. L. White, L. E. Ensminger, and F. E. Clark (Madison, WI: American Society of Agronomy), 1149-1178.

Brunner, I., and Sperisen, C. (2013). Aluminum exclusion and aluminum tolerance in woody plants. Front. Plant Sci. 4:172. doi: 10.3389/fpls.2013.00172

Chen, L. S. (2006). Physiological responses and tolerance of plant shoot to aluminium toxicity. J. Plant Physiol. Mol. Biol. 32, 143-155.

Choudhary, A. K., and Singh, D. (2011). Screening of pigeonpea genotypes for nutrient uptake efficiency under aluminium toxicity. Physiol. Mol. Biol. Plants 17, 145-152. doi: 10.1007/s12298-011-0057-7

Colla, G., Rouphael, Y., Cardarelli, M., Salerno, A., and Rea, E. (2010b). The effectiveness of grafting to improve alkalinity tolerance in watermelon. Environ. Exp. Bot. 68, 283-291. doi: 10.1016/j.envexpbot.2009.12.005

Colla, G., Rouphael, Y., Cardarelli, M., Temperini, O., Rea, E., and Salerno, A. (2008). Influence of grafting on yield and fruit quality of pepper (Capsicum annuиm L.) grown under greenhouse conditions. Acta Hort. 782, 359-363. doi: 10.17660/ActaHortic.2008.782.45

Colla, G., Rouphael, Y., Jawad, R., Kumar, P., Rea, E., and Cardarelli, M. (2013).The effectiveness of grafting to improve $\mathrm{NaCl}$ and $\mathrm{CaCl}_{2}$ tolerance in cucumber. $\mathrm{Sci}$. Hort. 164, 380-391. doi: 10.1016/j.scienta.2013.09.023

Colla, G., Rouphael, Y., Leonardi, C., and Bie, Z. (2010c). Role of grafting in vegetable crops grown under saline conditions. Sci. Hort. 127, 147-155. doi: 10.1016/j.scienta.2010.08.004

Colla, G., Rouphael, Y., Mirabelli, C., and Cardarelli, M. (2011). Nitrogen-use efficiency traits of mini-watermelon in response to grafting and nitrogenfertilization doses. J. Plant Nutr. Soil Sci. 174, 933-994. doi: 10.1002/jpln. 201000325

Colla, G., Rouphael, Y., Rea, E., and Cardarelli, M. (2012). Grafting cucumber plants enhance tolerance to sodium chloride and sulfate salinization. Sci. Hort. 135, 177-185. doi: 10.1016/j.scienta.2011.11.023

Colla, G., Suarez, C. M. C., Cardarelli, M., and Rouphael, Y. (2010a). Improving nitrogen use efficiency in melon by grafting. HortScience 45, 559-565.

Cristancho, R. J. A., Hanafi, M. M., Syed Omar, S. R., and Rafii, M. Y. (2011). Variations in oil palm (Elaeis guineensis Jacq.) progeny response to high aluminium concentrations in solution culture. Plant Biol. 13, 333-342. doi: $10.1111 /$ j.1438-8677.2010.00378.x tolerance to adverse $\mathrm{pH}$ conditions in the root zone" (20112013). Project partners: Department of Agricultural and Forestry Sciences, University of Tuscia, Viterbo (Italy), and LeibnizInstitute of Vegetable and Ornamental Crops (IGZ), Großbeeren (Germany).

Delhaize, E., and Ryan, P. R. (1995). Aluminium toxicity and tolerance in plants. Plant Physiol. 107, 315-321.

Delhaize, E., Ryan, P. R., and Randall, P. J. (1993). Aluminium tolerance in wheat (Triticum aestivum L.): II. Aluminium stimulated excretion of malic acid from root apices. Plant Physiol. 103, 695-702.

Dogan, I., Ozyigit, I. I., and Demir, G. (2014). Influence of aluminium on mineral nutrient uptake and accumulation in Urtica pilulifera L. J. Plant Nutr. 37, 469-481. doi: 10.1080/01904167.2013.864306

Edelstein, M., Ben-Hur, M., Cohen, R., Burger, Y., and Ravina, I. (2005). Boron and salinity effects on grafted and non-grafted melon plants. Plant Soil 269, 273-284. doi: 10.1007/s11104-004-0598-4

Edelstein, M., Ben-Hur, M., and Plaut, Z. (2007). Grafted melons irrigated with fresh or effluent water tolerate excess boron. J. Amer. Soc. Hort. Sci. 132, 484-491.

Gassmann, W., and Schroeder, J. I. (1994). Inward-rectifying $\mathrm{K}^{+}$channels in root hairs of wheat: a mechanism for aluminum-sensitive low-affinity $\mathrm{K}^{+}$uptake and membrane potential control. Plant Physiol. 105, 1399-1408.

Horst, W. J., Wang, Y., and Eticha, D. (2010). The role of the root apoplast in aluminium-induced inhibition of root elongation and in aluminium resistance of plants: a review. Ann. Bot. 106, 185-197. doi: 10.1093/aob/mcq053

Inostroza-Blancheteau, C., Rengel, Z., Alberdi, M., de la Luz Mora, M., Aquea, F., Arce-Johnson, P., et al. (2012). Molecular and physiological strategies to increase aluminum resistance in plants. Mol. Biol. Rep. 39, 2069-2079. doi: 10.1007/s11033-011-0954-4

Jones, D. L., Blancaflor, E. B., Kochian, L. V., and Gilroy, S. (2006). Spatial coordination of $\mathrm{Al}$ uptake, production of reactive oxygen species, callose production and wall rigidification in maize roots. Plant Cell Environ. 29, 1309-1318. doi: 10.1111/j.1365-3040.2006.01509.x

Karla, Y. P. (1998). Handbook of Reference Methods for Plant Analysis. Boca Raton, FL: CRC Press, 165-170.

Kochian, L. V. (1995). Cellular mechanisms of aluminum toxicity and resistance in plants. Annu. Rev. Plant Physiol. Plant Mol. Biol. 46, 237-260. doi: 10.1146/ annurev.pp.46.060195.001321

Kochian, L. V., Hoekenga, O. A., and Piñeros, M. (2004). How do crop plants tolerate acid soils? Mechanisms of aluminium tolerance and phosphorus efficiency. Annu. Rev. Plant Biol. 55, 549-593. doi: 10.1146/annurev. arplant.55.031903.141655

Kochian, L. V., Pineros, M. A., and Hoekenga, O. A. (2005). The physiology, genetics and molecular biology of plant aluminum resistance and toxicity. Plant Soil 274, 175-195. doi: 10.1007/s11104-004-1158-7

Kochian, L. V., Piñeros, M. A., Liu, J., and Magalhaes, J. V. (2015). Plant adaptation to acid soils: the molecular basis for crop aluminum resistance. Annu. Rev. Plant Biol. 66, 571-598. doi: 10.1146/annurev-arplant-043014-114822

Kumar, P., Lucini, L., Rouphael, Y., Cardarelli, C., Kalunke, R. M., and Colla, G. (2015a). Insight into the role of grafting and arbuscular mycorrhiza on cadmium stress tolerance in tomato. Front. Plant Sci. 6:477. doi: 10.3389/fpls.2015.00477

Kumar, P., Rouphael, Y., Cardarelli, M., and Colla, G. (2015b). Effect of nickel and grafting combination on yield, fruit quality, antioxidative enzyme activities, lipid peroxidation, and mineral composition of tomato. J. Plant Nutr. Soil Sci. 178, 848-860. doi: 10.1002/jpln.201400651

Kyriacou, M. C., Soteriou, G. A., Rouphael, Y., Siomos, A. S., and Gerasopoulos, D. (2016). Configuration of watermelon fruit quality in response to rootstockmediated harvest maturity and postharvest storage. J. Sci. Food Agric. 96, 2400-2409. doi: 10.1002/jsfa.7356

Lee, J. M., Kubota, C., Tsao, S. J., Biel, Z., Hoyos Echevaria, P., Morra, L., et al. (2010). Current status of vegetable grafting: diffusion, grafting techniques, automation. Sci. Hortic. 127, 93-105. doi: 10.1016/j.scienta.2010.08.003

Lutts, S., Kinet, J. M., and Bouharmont, J. (1995). Changes in plant response to $\mathrm{NaCl}$ during development of rice varieties differing in salinity resistance. J. Exp. Bot. 46, 1843-1852. doi: 10.1093/jxb/46.12.1843 
Nawrot, M., Szarejko, I., and Maluszynski, M. (2001). Barley mutants with increased tolerance to aluminium toxicity. Euphytica 120, 345-356. doi: 10.1023/A:1017565121835

Nogueirol, R. C., Monteiro, A. A., Gratao, P. L., Borgo, L., and Azevedo, R. A. (2015). Tropical soils with high aluminium concentrations cause oxidative stress in two tomato genotypes. Environ. Monit. Assess. 187, 73. doi: 10.1007/ s10661-015-4282-3

Panda, S., and Matsumoto, H. (2007). Molecular physiology of aluminum toxicity and tolerance in plants. Bot. Rev. 73, 326-347. doi: 10.1663/00068101(2007)73[326:MPOATA]2.0.CO;2

Pécsváradi, A., Nagy, Z., Varga, A., Vashegyi, A., Labádi, I., Galbács, G., et al. (2009). Chloroplastic glutamine synthetase is activated by direct binding of aluminium. Physiol. Plant. 135, 43-50. doi: 10.1111/j.1399-3054.2008.01167.x

Pereira, L. B., Mazzanti, C. M. A., Goncalves, J. F., Cargnelutti, D., Tabaldi, L. A., Becker, A. G., et al. (2010). Aluminium-induced oxidative stress in cucumber. Plant Physiol. Biochem. 48, 683-689. doi: 10.1016/j.plaphy.2010.04.008

Piñeros, M., and Tester, M. (1995). Characterization of a voltage-dependent $\mathrm{Ca}^{2+}$ selective channel from wheat roots. Planta 195, 478-488.

Proietti, S., Rouphael, Y., Colla, G., Cardarelli, M., De Agazio, M., Zacchini, M., et al. (2008). Fruit Quality of Mini-watermelon as affected by and irrigation regimes. J. Sci. Food Agric. 88, 1107-1114. doi: 10.1002/jsfa.3207

Rangel, A. F., Mobin, M., Rao, I. M., and Horst, W. J. (2005). Proton toxicity interferes with the screening of common bean (Phaselous vulgaris L.) genotypes for aluminium resistance in nutrient solution. J. Plant Nutr. Soil Sci. 168, 607-616. doi: 10.1002/jpln.200520509

Rengel, Z., Bose, J., Chen, Q., and Tripathi, B. N. (2015). Magnesium alleviates plant toxicity of aluminium and heavy metals. Crop Past. Sci. 66, 1298-1307. doi: $10.1071 / \mathrm{CP} 15284$

Rengel, Z., and Elliott, D. C. (1992). Mechanism of aluminum inhibition of net $\mathrm{Ca}^{2+}$ uptake by Amaranthus protoplasts. Plant Physiol. 98, 632-638. doi: 10.1104/pp.98.2.632

Rengel, Z., and Robinson, D. L. (1989). Aluminum and plant age effects on absorption of cations in the Donnan Free space of ryegrass roots. Plant Soil 6, 223-227. doi: 10.1007/BF02214551

Rengel, Z., and Zhang, W. H. (2003). Role of dynamics of intracellular calcium and aluminium-toxicity syndrome. New Phytol. 159, 295-314. doi: 10.1046/j.14698137.2003.00821.x

Rouphael, Y., Cardarelli, M., Bassal, A., Leonardi, C., Giuffrida, F., and Colla, G. (2012). Vegetable quality as affected by genetic, agronomic and environmental factors. J. Food Agric. Environ. 10, 680-688.

Rouphael, Y., Cardarelli, M., and Colla, G. (2015). Role of arbuscular mycorrhizal fungi in alleviating the adverse effects of acidity and aluminium toxicity in zucchini squash. Sci. Hortic. 188, 97-105. doi: 10.1016/j.scienta.2015.03.031

Rouphael, Y., Cardarelli, M., Colla, G., and Rea, E. (2008b). Yield, mineral composition, water relations, and water use efficiency of grafted miniwatermelon plants under deficit irrigation. HortScience 43, 730-736.
Rouphael, Y., Cardarelli, M., Di Mattia, E., Tullio, M., Rea, E., and Colla, G. (2010). Enhancement of alkalinity tolerance in two cucumber genotypes inoculated with an arbuscular mycorrhizal biofertilizer containing Glomus intraradices. Biol. Fert. Soils 46, 409-509. doi: 10.1007/s00374-010-0457-9

Rouphael, Y., Cardarelli, M., Rea, E., and Colla, G. (2008a). Grafting of cucumber as a means to minimize copper toxicity. Environ. Exp. Bot. 63, 49-58. doi: 10.1016/j.envexpbot.2007.10.015

Ryan, P., Delhaize, E., and Jones, D. (2001). Function and mechanism of organic anion exudation from plant roots. Annu. Rev. Plant Physiol. Plant Mol. Biol. 52, 527-560. doi: 10.1146/annurev.arplant.52.1.527

Savvas, D., Colla, G., Rouphael, Y., and Schwarz, D. (2010). Amelioration of heavy metal and nutrient stress in fruit vegetables by grafting. Sci. Hortic. 127, 156-161. doi: 10.1016/j.scienta.2010.09.011

Savvas, D., Ntatsi, G., and Barouchas, P. (2013). Impact of grafting and rootstock genotype on cation uptake by cucumber (Cucumis sativus L.) exposed to Cd or Ni stress. Sci. Hortic. 149, 86-96. doi: 10.1016/j.scienta.2012.06.030

Seguel, A., Cumming, J. R., Klugh-Stewart, K., Cornejo, P., and Borie, F. (2013). The role of arbuscular mycorrhizas in decreasing aluminium phototoxicity in acidic soils: a review. Mycorrhiza 23, 167-183. doi: 10.1007/s00572-0130479-x

Simon, L., Smalley, T. J., Jones, J. B., and Lasseigne, F. T. (1994). Aluminum toxicity in tomato. Part 2. Leaf gas exchange, chlorophyll content, and invertase activity. J. Plant Nutr. 17, 307-317. doi: 10.1080/01904169409364729

Sivaguru, M., Liu, J., and Kochian, L. V. (2013). Targeted expression of SbMATE in the root distal transition zone is responsible for sorghum aluminum resistance. Plant J. 76, 297-307. doi: 10.1111/tpj.12290

SPSS (2001). SPSS 10 for Windows. Applications Guide. Chicago, IL: SPSS Inc.

Yang, M. Z., Sivaguru, M., Horts, W. J., and Matsumoto, H. (2000). Aluminium tolerance is achieved by exudation of citric acid from roots of soybean (Glycine max). Physiol. Plant. 110, 72-77. doi: 10.1034/j.1399-3054.2000. 110110.x

Yang, Z. B., Rao, I. M., and Horst, W. J. (2013). Interaction of aluminium and drought stress on root growth and crop yield on acid soils. Plant Soil 372, 3-25. doi: 10.1007/s11104-012-1580-1

Conflict of Interest Statement: The authors declare that the research was conducted in the absence of any commercial or financial relationships that could be construed as a potential conflict of interest.

Copyright (c) 2016 Rouphael, Rea, Cardarelli, Bitterlich, Schwarz and Colla. This is an open-access article distributed under the terms of the Creative Commons Attribution License (CC BY). The use, distribution or reproduction in other forums is permitted, provided the original author(s) or licensor are credited and that the original publication in this journal is cited, in accordance with accepted academic practice. No use, distribution or reproduction is permitted which does not comply with these terms. 